\title{
Chemical Characterization of Lignin and Lipid Fractions in Kenaf Bast Fibers Used for Manufacturing High-Quality Papers
}

\author{
Ana GutiÉrRez,* IsAbel M. Rodríguez, AND José C. DEl Río
}

Instituto de Recursos Naturales y Agrobiología, CSIC, P.O. Box 1052, 41080 Seville, Spain

\begin{abstract}
The chemical composition of lignin and lipids of bast fibers from kenaf (Hibiscus cannabinus) used for high-quality paper pulp production was studied. Pyrolysis-gas chromatography/mass spectrometry (Py-GC/MS) of fibers showed a lignin with a high syringyl/guaiacyl ratio (5.4) and minor amounts of p-hydroxyphenyl units. Simultaneously, sinapyl and coniferyl acetates were also identified, indicating that this lignin is partially acetylated. $p$-Hydroxycinnamic acids were found in only trace amounts. The main lipids identified by GC/MS of extracts from kenaf fibers were series of long-chain $n$-fatty acids, waxes, $n$-alkanes, and $n$-fatty alcohols. Free and esterified sterols and triterpenols, steroid hydrocarbons, and steroid and triterpenoid ketones, as well as steryl glycosides, were also found. Finally, the fate of the main constituents of kenaf fibers in alkaline pulping was also investigated.
\end{abstract}

KEYWORDS: Kenaf; Hibiscus cannabinus; bast fibers; lipids; lignin; acetylated lignin, steroids

\section{INTRODUCTION}

Nonwood plants are the common fiber source for paper pulp production in developing countries where wood fibers are not available. In the developed world, although wood is still by far the main raw material for paper pulp manufacture, a market exists for high-value-added papers from these fibers (1). Kenaf (Hibiscus cannabinus) is an annual dicotyledonous plant of the Malvaceae family, which grows in temperate and tropical areas and has received increasing interest in the pulp and paper industry $(2,3)$. The kenaf plant contains moderately long fibers in its outer stem (bast) and short fibers in its core, both of which are suitable for paper and other products $(4,5)$. However, the bast fibers are especially suitable for manufacturing specialty papers such as coffee filters and teabags.

Studies on the chemical composition of kenaf bast fibers are important for optimizing the pulping and bleaching processes of this raw material. Among the several parameters that may affect pulp production are the composition of lignin and lipids in fibers. In general, the efficiency of pulping is directly proportional to the amount of syringyl (S) units in lignin (6). The guaiacyl $(\mathrm{G})$ units have a free $\mathrm{C}-5$ position available for carbon-carbon interunit bonds, which make them fairly resistant to lignin depolymerization in pulping. On the other hand, it is well-known that lipophilic compounds present in raw materials cause significant environmental and technical problems in the manufacturing of paper pulp. During pulping, lipids are released from the fibers, forming colloidal pitch, which can deposit in either pulp or machinery causing production troubles $(7,8)$. In the manufacture of alkaline pulps, a large part of the lipids originally present in the raw material is removed during the cooking. However, some chemical species survive these pro-

* Author to whom correspondence should be addressed (telephone +34-95-4624711; fax +34-95-4624002; e-mail anagu@irnase.csic.es). cesses and are found as pulp extractives, suspended in process waters or forming the so-called pitch deposits in circuits, equipment, and final product (9). Moreover, such extractives might contribute to the toxicity of paper pulp effluents and products (10).

Several studies have been published regarding the composition of in situ or isolated lignin of kenaf fibers using different methodologies $(11-16)$. On the other hand, studies regarding the composition of lipids from kenaf fibers have been scarce (17). In the present study we have characterized the lignin in kenaf bast fibers using analytical pyrolysis coupled to gas chromatography/mass spectrometry (Py-GC/MS). Py-GC/MS is a powerful analytical tool for the rapid analysis of complex polymer mixtures including lignocellulosic materials $(18,19)$. It combines rapid thermal degradation and GC/MS of marker compounds from pyrolytic breakdown. We also performed a detailed analysis of the chemical composition of lipids from kenaf bast fibers. These analyses were carried out by GC and GC/MS using short- and medium-length high-temperature capillary columns, respectively, with thin films (20). This method enables the elution and analysis of intact high molecular weight lipids such as waxes, sterol esters, and triglycerides. Finally, the fate of kenaf lignin and lipids in alkaline pulping of these fibers was also studied.

\section{MATERIALS AND METHODS}

Samples. Kenaf (H. cannabinus) bast fibers (from China) and the alkaline pulp (kappa 6) made therefrom were supplied by CELESA pulp mill (Tortosa, Spain). Kenaf fibers contained $15 \%$ of core fibers, and the pulp was obtained by soda-anthraquinone (AQ) cooking (21). Kenaf bast fibers were air-dried, whereas the pulp sample was dried in an aerated oven at $50{ }^{\circ} \mathrm{C}$. The dried samples were milled using a knife mill (Janke and Kunkel, Analysenmühle). For the study of lignin composition of fibers and pulp, milled samples were analyzed by Py- 
GC/MS. For the analysis of lipid composition, milled samples were extracted with acetone in a Soxhlet apparatus for $8 \mathrm{~h}$. The extracts were evaporated to dryness and resuspended in chloroform for chromatographic analysis of the lipophilic fraction. Two replicates were used for each sample, and all samples were subjected to GC and GC/ MS analyses. For hemicellulose analysis and lignin content estimation, milled samples were successively extracted with acetone ( $8 \mathrm{~h}$ in Soxhlet) and hot water $\left(3 \mathrm{~h}\right.$ at $\left.100{ }^{\circ} \mathrm{C}\right)$. Klason lignin was estimated as the residue after sulfuric acid hydrolysis of the pre-extracted material, and sugars from polysaccharide hydrolysis were analyzed as alditol acetates by GC according to Tappi rules T222 om-88 and T249 om85 (22), respectively. Ash content was estimated as the residue after $6 \mathrm{~h}$ at 575 ${ }^{\circ} \mathrm{C}$.

GC and GC/MS Analyses. An HP 5890 gas chromatograph (Hewlett-Packard, Hoofddorp, The Netherlands) equipped with a splitsplitless injector and a flame ionization detector (FID) was used for GC analyses of the lipophilic compounds. The injector and the detector temperatures were set at 300 and $350{ }^{\circ} \mathrm{C}$, respectively. Samples were injected in the splitless mode. Helium was used as the carrier gas. The capillary column used was a $5 \mathrm{~m} \times 0.25 \mathrm{~mm}$ i.d., $0.1 \mu \mathrm{m}$, hightemperature, polyimide-coated fused silica tubing DB-5HT from J\&W Scientific (Folsom, CA), especially processed for use at $400{ }^{\circ} \mathrm{C}$. The oven was temperature programmed from $100{ }^{\circ} \mathrm{C}(1 \mathrm{~min})$ to $350{ }^{\circ} \mathrm{C}(3$ min) at $15{ }^{\circ} \mathrm{C} / \mathrm{min}$. Peaks were quantified by area, and a mixture of standards (octadecane, palmitic acid, sitosterol, cholesteryl oleate, and campesteryl, stigmasteryl, and sitosteryl 3- $\beta$-D-glucopyranosides) was used to elaborate calibration curves. The data from the two replicates were averaged. In all cases the standard deviations from replicates were below $10 \%$ of the mean values.

The GC/MS analyses were performed on a model GC 8000 Top gas chromatograph (Thermo Finnigan, San Jose, CA) coupled to a Voyager quadrupole mass spectrometer detector (ThermoQuest Finnigan) equipped with a $15 \mathrm{~m} \times 0.25 \mathrm{~mm}$ i.d., $0.1 \mu \mathrm{m}$, DB-5HT fused silica capillary column $(\mathrm{J} \& \mathrm{~W})$. The oven was heated from $120{ }^{\circ} \mathrm{C}(1$ min) to $380{ }^{\circ} \mathrm{C}(5 \mathrm{~min})$ at $10{ }^{\circ} \mathrm{C} / \mathrm{min}$. The injector and transfer line temperatures were set at 300 and $350{ }^{\circ} \mathrm{C}$, respectively. Helium was used as the carrier gas, and the injection was performed in splitless mode. Bis(trimethylsilyl)trifluoroacetamide (BSTFA) silylation was used when required. Compounds were identified by comparing their mass spectra with mass spectra in the Wiley and NIST libraries, by mass fragmentography, and, when possible, by comparison with authentic standards.

Py-GC/MS. The pyrolysis of kenaf fibers and pulp was performed in duplicate with a Curie-point pyrolyzer (Horizon Instruments Ltd.) coupled to a Varian Saturn 2000 GC/MS, using a $30 \mathrm{~m} \times 0.25 \mathrm{~mm}$ i.d., $0.25 \mu \mathrm{m}$, DB-5 column. Approximately $100 \mu \mathrm{g}$ of finely divided sample was deposited on a ferromagnetic wire, then inserted into the glass liner, and immediately placed in the pyrolyzer. The pyrolysis was carried out at $610^{\circ} \mathrm{C}$ for $4 \mathrm{~s}$. The chromatograph was programmed from $40{ }^{\circ} \mathrm{C}(1 \mathrm{~min})$ to $300{ }^{\circ} \mathrm{C}$ at a rate of $6{ }^{\circ} \mathrm{C} / \mathrm{min}$. The final temperature was held for $20 \mathrm{~min}$. The injector, equipped with a liquid carbon dioxide cryogenic unit, was programmed from $-30{ }^{\circ} \mathrm{C}(1 \mathrm{~min})$ to $300{ }^{\circ} \mathrm{C}$ at $200^{\circ} \mathrm{C} / \mathrm{min}$, whereas the $\mathrm{GC} / \mathrm{MS}$ interface was kept at $300^{\circ} \mathrm{C}$. For the pyrolysis in the presence of tetramethylammonium hydroxide (TMAH), to analyze $p$-hydroxycinnamic acids, $\sim 100 \mu \mathrm{g}$ of sample was mixed with $0.5 \mu \mathrm{L}$ of $25 \%$ TMAH. The wire was then inserted into the glass liner, which was subsequently placed in the pyrolyzer. The pyrolysis was carried out as described above. The compounds were identified by comparing the mass spectra obtained with those of the Wiley and NIST computer libraries and that reported in the literature $(18,19)$. Relative peak molar areas were calculated for carbohydrate and lignin pyrolysis products. The summed molar areas of the relevant peaks were normalized to $100 \%$, and the data for two repetitive pyrolysis experiments were averaged. The relative standard deviation for the pyrolysis data was $<10 \%$. No attempt was made to calculate the response factor for every single compound released. However, for most of the lignin-derived phenols, the response factors are nearly identical (23), with the exception of vanillin, but this is a minor peak here.
Table 1. Chemical Composition of Kenaf Fibers and Their Alkaline Pulp (Percent)

\begin{tabular}{lrrlrc}
\hline & fibers & pulp & & fibers & pulp \\
\hline ash & 1.8 & 2.1 & xylose & 11.0 & 12.7 \\
extractives & 1.0 & 0.3 & mannose & 4.2 & 1.0 \\
water-soluble & & 0.7 & galactose & 2.5 & 0 \\
lignin & 11.4 & 0.8 & glucose & 63.8 & 80.3 \\
arabinose & 2.4 & 1.1 & & & \\
& & & & & \\
\hline
\end{tabular}

\section{RESULTS AND DISCUSSION}

The composition on the main constituents of kenaf bast fibers is shown in Table 1. The lignin content accounted for $11 \%$ of fibers. This value is higher than for other nonwood bast fibers such as hemp but lower than for wood (24). The content of lipids was $\sim 1 \%$, similar to that of hemp but lower than that of other nonwood materials used for papermaking, such as flax $(25,26)$. The hemicellulose fraction was mainly constituted by xylose and mannose. The composition of the kenaf alkaline pulp (kappa 6) selected for this study is also shown in Table 1. A decrease of the hemicellulose content could be observed after pulping, but most hemicellulose remained in the pulp due to xylan resistance toward alkaline cooking. The glucan content, mainly corresponding to cellulose, increased during pulping. The major part of the lignin in kenaf fibers was removed during pulping, although some residual lignin remained in the unbleached pulp. About one-third of the lipophilic extractives also remained in the pulp.

Lignin Composition. To analyze in situ the chemical composition of lignin, the kenaf bast fibers were subjected to Py-GC/MS. The Py-GC/MS chromatogram is shown in Figure $\mathbf{1}$, and the identities and relative abundances of the released compounds are listed in Table 2. Carbohydrate pyrolysis products represented $35 \%$ on average and phenols from lignin represented $65 \%$ of the total identified compounds from kenaf fibers. The pyrogram of kenaf bast fibers showed compounds derived from guaiacyl $(\mathrm{G})$ and syringyl (S) lignin units, with a very strong predominance of the $S$ units $(S / G$ molar ratio of 5.4). Compounds derived from $p$-hydroxyphenyl $(\mathrm{H})$ lignin units were found in minor amounts (1.4\% of typical lignin-derived compounds). The main lignin-derived compounds identified were syringol (34), 4-methylsyringol (39), 4-vinylsyringol (47), 4-allylsyringol (49), and cis- and trans-4-propenylsyringol (51 and 55). Syringaldehyde (52), syringylacetone (59), transsinapaldehyde (63), and cis- and trans-sinapyl alcohol (62 and 64) were also identified. The guaiacyl counterparts were also detected, although in lower amounts. The high $\mathrm{S} / \mathrm{G}$ ratio observed in the lignin of bast fibers upon Py-GC/MS is in agreement with the values reported by other authors $(11,14-$ 16). In contrast, some authors $(12,13)$ have reported higher proportions of $\mathrm{G}$ over $\mathrm{S}$ lignin units of kenaf bast fibers. On the other hand, the low content of $\mathrm{H}$ units found after Py-GC/ MS of kenaf fibers agrees with most previous works $(15,16)$. However, Neto et al. (12) reported a high content of $\mathrm{H}$ lignin units in kenaf, as compared to other dicotyledoneous lignins. The authors claimed that the high $\mathrm{H}$ lignin content could be due to the presence of $p$-coumaric acid type structures. In the present work, we analyzed the presence of cinnamic acids using $\mathrm{Py}-\mathrm{GC} / \mathrm{MS}$ in the presence of TMAH, and methyl derivatives of $p$-coumaric and ferulic acids (4-methoxycinnamic acid and 3,4-dimethoxycinnamic acid methyl esters, respectively) were found in only trace amounts (cinnamic acids/lignin molar ratio of 0.03 ), with a predominance of ferulic acid over $p$-coumaric 

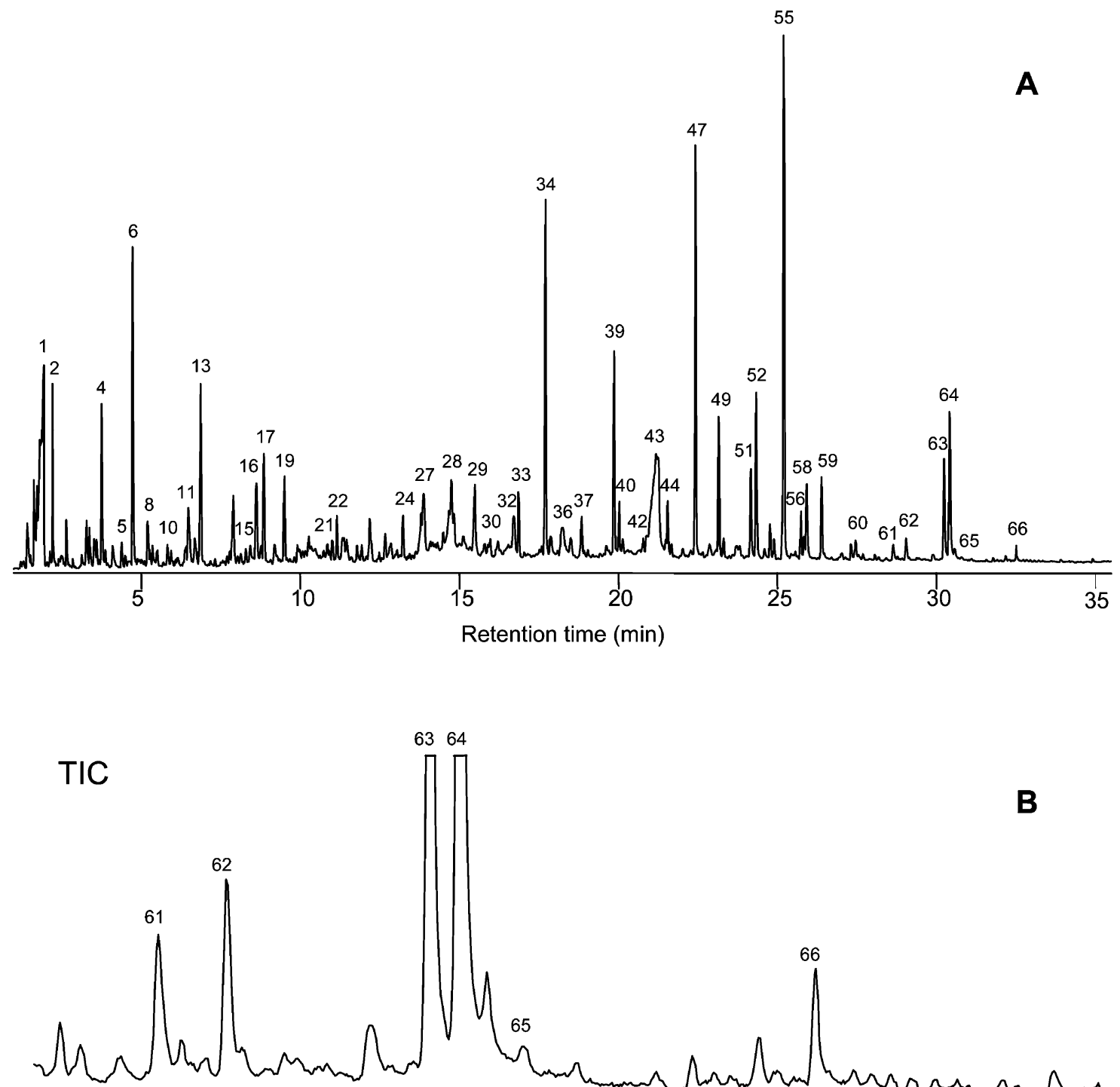

6364
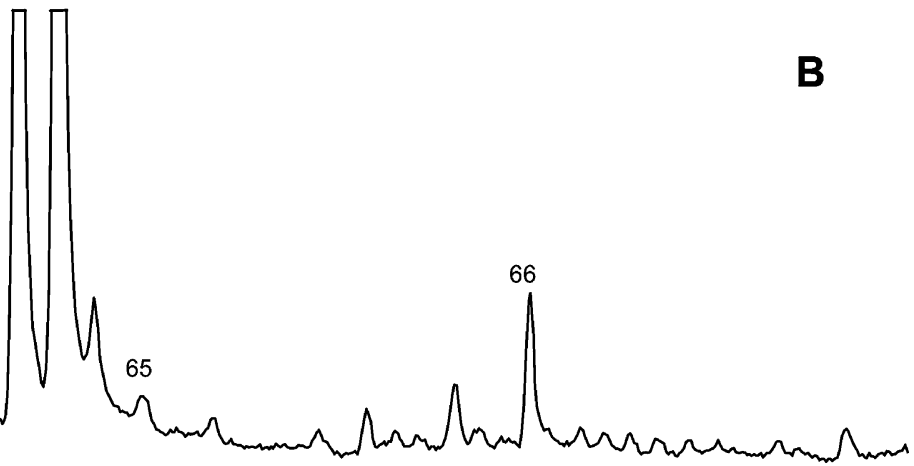

$m / z 252$
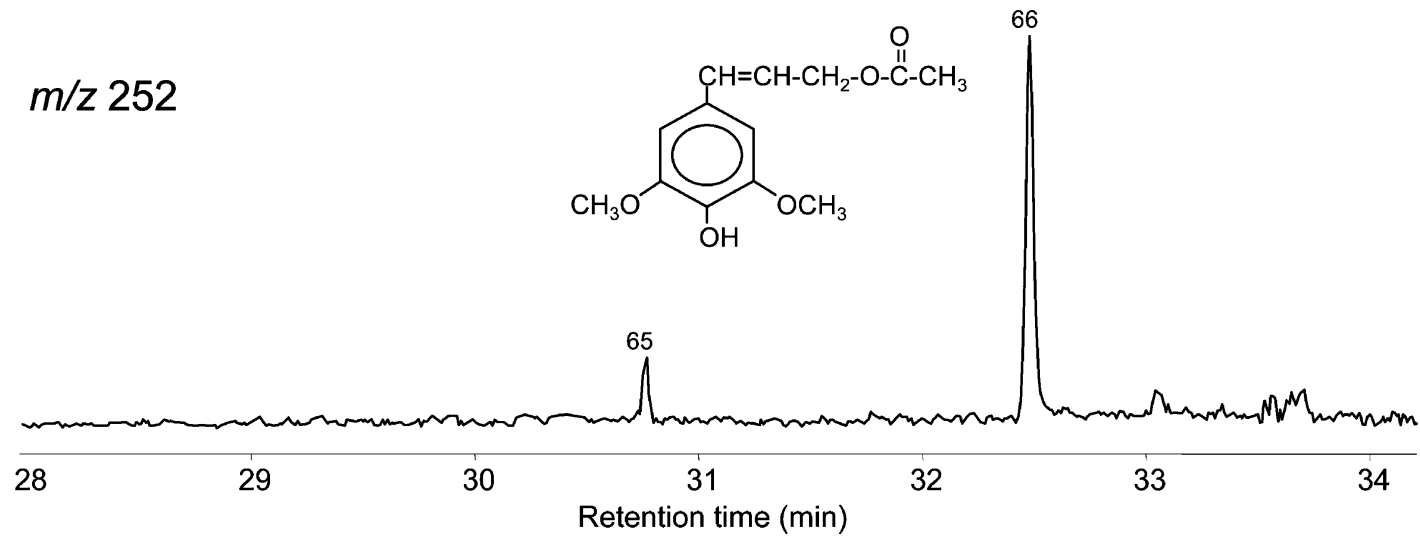

Figure 1. (A) Py-GC/MS chromatogram of kenaf bast fibers and (B) detail of the total ion chromatogram (TIC) and chromatogram of the ion at $\mathrm{m} / \mathrm{z} 252$ showing the presence of sinapyl acetates. The identities of the compounds are listed in Table 2.

acid (1.73 of molar ratio). This result agrees with the low amount of cinnamic acids in kenaf bast fibers reported in other works $(13,16)$.

A detailed analysis of the compounds released after Py-GC/ MS of kenaf bast fibers revealed the presence of sinapyl acetate [3-(4-hydroxy-3,5-dimethoxyphenyl)-2-propen-1-ol acetate] in cis and trans forms. Minor amounts of coniferyl acetates (cis and trans forms) were also detected. Acetylated lignin units have already been reported to occur in kenaf (11); however, this is the first time that the presence of acetylated lignin units has been shown using Py-GC/MS. Sinapyl and coniferyl acetates have also been detected for the first time in other nonwood fibers with high $\mathrm{S} / \mathrm{G}$ ratios such as sisal, abaca, and jute (27). The presence of sinapyl acetates in kenaf bast fibers is shown in Figure 1. A predominance of the trans over the cis form was observed, similar to that of the respective nonacetylated sinapyl alcohols. Previous NMR and degradative studies $(11,28)$ have shown that lignin in kenaf is acetylated at the $\gamma$-position of the 
Table 2. Compounds Released after Py-GC/MS of Kenaf Fibers ${ }^{a}$

\begin{tabular}{|c|c|c|c|c|c|c|}
\hline no. & compound & mass fragments & MW & formula & origin & $\%$ \\
\hline 1 & hydroxyacetaldehyde & $42 / 60$ & 60 & $\mathrm{C}_{2} \mathrm{H}_{4} \mathrm{O}_{2}$ & C & 12.1 \\
\hline 2 & 3-hydroxypropanal & $73 / 74$ & 74 & $\mathrm{C}_{3} \mathrm{H}_{6} \mathrm{O}_{2}$ & C & 1.1 \\
\hline 3 & $(3 \mathrm{H})$-furan-2-one & $55 / 84$ & 84 & $\mathrm{C}_{4} \mathrm{H}_{4} \mathrm{O}_{2}$ & $\mathrm{c}$ & 0.2 \\
\hline 4 & unknown & $56 / 57 / 87$ & & & & 2.9 \\
\hline 5 & $(2 H)$-furan-3-one & $55 / 84$ & 84 & $\mathrm{C}_{4} \mathrm{H}_{4} \mathrm{O}_{2}$ & C & 0.3 \\
\hline 6 & 2-furaldehyde & $67 / 95 / 96$ & 96 & $\mathrm{C}_{5} \mathrm{H}_{4} \mathrm{O}_{2}$ & $\mathrm{c}$ & 3.3 \\
\hline 7 & 2-methylfuran & $53 / 81 / 82$ & 82 & $\mathrm{C}_{5} \mathrm{H}_{6} \mathrm{O}$ & C & 0.3 \\
\hline 8 & 2-(hydroxymethyl)furan & $43 / 70 / 81 / 98$ & 98 & $\mathrm{C}_{5} \mathrm{H}_{6} \mathrm{O}_{2}$ & $\mathrm{C}$ & 1.0 \\
\hline 9 & cyclopent-1-ene-3,4-dione & $54 / 68 / 96$ & 96 & $\mathrm{C}_{5} \mathrm{H}_{4} \mathrm{O}_{2}$ & C & 0.3 \\
\hline 10 & 4-methyltetrahydrofuran-3-one & $43 / 72$ & 100 & $\mathrm{C}_{5} \mathrm{H}_{8} \mathrm{O}_{2}$ & C & 0.6 \\
\hline 11 & (5H)-furan-2-one & $55 / 84$ & 84 & $\mathrm{C}_{4} \mathrm{H}_{4} \mathrm{O}_{2}$ & $\mathrm{C}$ & 1.2 \\
\hline 12 & acetylfuran & $43 / 95 / 110$ & 110 & $\mathrm{C}_{6} \mathrm{H}_{6} \mathrm{O}_{2}$ & C & 0.1 \\
\hline 13 & 2,3-dihydro-5-methylfuran-2-one & $55 / 69 / 98$ & 98 & $\mathrm{C}_{5} \mathrm{H}_{6} \mathrm{O}_{2}$ & $\mathrm{C}$ & 3.6 \\
\hline 14 & 5-methyl-2-furfuraldehyde & $53 / 109 / 110$ & 110 & $\mathrm{C}_{6} \mathrm{H}_{6} \mathrm{O}_{2}$ & $\mathrm{C}$ & 0.2 \\
\hline 15 & phenol & $65 / 66 / 94$ & 94 & $\mathrm{C}_{5} \mathrm{H}_{6} \mathrm{O}$ & LH & 0.2 \\
\hline 16 & 5,6-dihydropyran-2,5-dione & $68 / 98$ & 98 & $\mathrm{C}_{5} \mathrm{H}_{6} \mathrm{O}_{2}$ & $\mathrm{c}$ & 1.6 \\
\hline 17 & 4-hydroxy-5,6-dihydro-(2H)-pyran-2-one & $58 / 85 / 114$ & 114 & $\mathrm{C}_{5} \mathrm{H}_{6} \mathrm{O}_{3}$ & C & 1.4 \\
\hline 18 & 3-hydroxy-2-methyl-2-cyclopenten-1-one & $55 / 84 / 112$ & 112 & $\mathrm{C}_{6} \mathrm{H}_{8} \mathrm{O}_{2}$ & $\mathrm{C}$ & 0.5 \\
\hline 19 & 2-hydroxy-3-methyl-2-cyclopenten-1-one & $55 / 84 / 112$ & 112 & $\mathrm{C}_{6} \mathrm{H}_{8} \mathrm{O}_{2}$ & $\mathrm{C}$ & 1.9 \\
\hline 20 & 4-methylphenol & $77 / 107 / 108$ & 108 & $\mathrm{C}_{7} \mathrm{H}_{8} \mathrm{O}$ & $\mathrm{LH}$ & 0.3 \\
\hline 21 & 2-furoic acid, methyl ester & $67 / 95 / 126$ & 126 & $\mathrm{C}_{6} \mathrm{H}_{6} \mathrm{O}_{3}$ & $\mathrm{C}$ & 0.4 \\
\hline 22 & guaiacol & $81 / 109 / 124$ & 124 & $\mathrm{C}_{7} \mathrm{H}_{8} \mathrm{O}_{2}$ & LG & 0.9 \\
\hline 23 & 4-ethylphenol & $77 / 107 / 122$ & 122 & $\mathrm{C}_{8} \mathrm{H}_{10} \mathrm{O}_{2}$ & $\mathrm{LH}$ & 0.1 \\
\hline 24 & 3,4-dihydroxybenzaldehyde & $81 / 109 / 137 / 138$ & 138 & $\mathrm{C}_{7} \mathrm{H}_{6} \mathrm{O}_{3}$ & LM & 0.6 \\
\hline 25 & 5-hydroxymethyl-2-tetrahydrofuraldehyde-3-one & $43 / 57 / 69 / 70 / 85$ & 144 & $\mathrm{C}_{6} \mathrm{H}_{8} \mathrm{O}_{4}$ & $\mathrm{C}$ & 0.7 \\
\hline 26 & 4-methylquaiacol & $95 / 123 / 138$ & 138 & $\mathrm{C}_{8} \mathrm{H}_{10} \mathrm{O}_{2}$ & LG & 0.2 \\
\hline 27 & 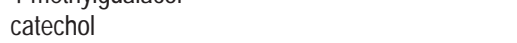 & $64 / 81 / 92 / 110$ & 110 & $\mathrm{C}_{6} \mathrm{H}_{6} \mathrm{O}_{2}$ & $\mathrm{LM} / \mathrm{C}$ & 2.3 \\
\hline 28 & 5-hydroxymethyl-2-furaldehyde & $69 / 97 / 109 / 126$ & 126 & $\mathrm{C}_{6} \mathrm{H}_{6} \mathrm{O}_{3}$ & $\mathrm{C}$ & 1.4 \\
\hline 29 & 3-methoxycatechol & $79 / 97 / 125 / 140$ & 140 & $\mathrm{C}_{7} \mathrm{H}_{8} \mathrm{O}_{3}$ & LM & $\begin{array}{l}1.4 \\
1.5\end{array}$ \\
\hline 30 & 4-ethylguaiacol & $122 / 137 / 152$ & 152 & $\mathrm{C}_{9} \mathrm{H}_{12} \mathrm{O}_{2}$ & LG & 0.3 \\
\hline 31 & 4-methylcatechol & $78 / 107 / 123 / 124$ & 124 & $\mathrm{C}_{7} \mathrm{H}_{8} \mathrm{O}_{2}$ & LM & 0.2 \\
\hline 32 & 1,4-dideoxy-D-glycerohex-1-enepyrenone-3-ulone & $43 / 73 / 87 / 113 / 144$ & 144 & $\mathrm{C}_{6} \mathrm{H}_{8} \mathrm{O}_{4}$ & $\mathrm{C}$ & 0.8 \\
\hline 33 & 4-vinylguaiacol & $107 / 135 / 150$ & 150 & $\mathrm{C}_{9} \mathrm{H}_{10} \mathrm{O}_{2}$ & $L G$ & 1.1 \\
\hline 34 & syringol & $111 / 139 / 154$ & 154 & $\mathrm{C}_{8} \mathrm{H}_{10} \mathrm{O}_{3}$ & LS & 6.2 \\
\hline 35 & eugenol & $131 / 149 / 164$ & 164 & $\mathrm{C}_{10} \mathrm{H}_{12} \mathrm{O}_{2}$ & LG & 0.5 \\
\hline 36 & pyrogallol & $52 / 80 / 97 / 108 / 126$ & 126 & $\mathrm{C}_{6} \mathrm{H}_{6} \mathrm{O}_{3}$ & LM & 2.1 \\
\hline 37 & vanillin & $109 / 151 / 152$ & 152 & $\mathrm{C}_{8} \mathrm{H}_{8} \mathrm{O}_{3}$ & LG & 0.6 \\
\hline 38 & cis-isoeugenol & $131 / 149 / 164$ & 164 & $\mathrm{C}_{10} \mathrm{H}_{12} \mathrm{O}_{2}$ & $L G$ & 0.1 \\
\hline 39 & 4-methylsyringol & $125 / 153 / 168$ & 168 & $\mathrm{C}_{9} \mathrm{H}_{12} \mathrm{O}_{2}$ & LS & 2.4 \\
\hline 40 & trans-isoeugenol & $131 / 149 / 164$ & 164 & $\mathrm{C}_{10} \mathrm{H}_{12} \mathrm{O}_{2}$ & LG & 0.8 \\
\hline 41 & homovanillin & $122 / 137 / 166$ & 166 & $\mathrm{C}_{10} \mathrm{H}_{14} \mathrm{O}_{2}$ & LG & 0.3 \\
\hline 42 & acetoguaiacone & $123 / 151 / 166$ & 166 & $\mathrm{C}_{9} \mathrm{H}_{10} \mathrm{O}_{3}$ & LG & 0.3 \\
\hline 43 & levoglucosane & $57 / 60 / 73 / 98$ & 162 & $\mathrm{C}_{6} \mathrm{H}_{10} \mathrm{O}_{5}$ & $\mathrm{C}$ & 10.0 \\
\hline 44 & 4-ethylsyringol & $167 / 182$ & 182 & $\mathrm{C}_{10} \mathrm{H}_{14} \mathrm{O}_{3}$ & LS & 0.9 \\
\hline 45 & guaiacylacetone & $122 / 137 / 180$ & 180 & $\mathrm{C}_{10} \mathrm{H}_{12} \mathrm{O}_{3}$ & LG & 0.2 \\
\hline 46 & 1,6 -anhydro- $\beta$-D-glucofuranose & $73 / 85 / 115$ & 162 & $\mathrm{C}_{6} \mathrm{H}_{10} \mathrm{O}_{5}$ & $\mathrm{C}$ & 0.3 \\
\hline 47 & 4 -vinylsyringol & $137 / 165 / 180$ & 180 & $\mathrm{C}_{10} \mathrm{H}_{12} \mathrm{O}_{3}$ & LS & 6.3 \\
\hline 48 & guaiacyl vinyl ketone & $123 / 151 / 178$ & 178 & $\mathrm{C}_{10} \mathrm{H}_{10} \mathrm{O}_{3}$ & LG & 0.1 \\
\hline 49 & 4-allylsyringol & $167 / 179 / 194$ & 194 & $\mathrm{C}_{11} \mathrm{H}_{14} \mathrm{O}_{3}$ & LS & 1.7 \\
\hline 50 & 4-propylsyringol & $123 / 167 / 196$ & 196 & $\mathrm{C}_{11} \mathrm{H}_{16} \mathrm{O}_{3}$ & LS & 0.3 \\
\hline 51 & cis-4-propenylsyringol & $167 / 179 / 194$ & 194 & $\mathrm{C}_{11} \mathrm{H}_{11} \mathrm{O}_{3}$ & LS & 1.3 \\
\hline 52 & syringaldehyde & $167 / 181 / 182$ & 182 & $\mathrm{C}_{9} \mathrm{H}_{10} \mathrm{O}_{4}$ & LS & 2.4 \\
\hline 53 & cis-coniferyl alcohol & $124 / 137 / 151 / 180$ & 180 & $\mathrm{C}_{10} \mathrm{H}_{12} \mathrm{O}_{3}$ & $L G$ & 0.3 \\
\hline 54 & 4-propinylsyringol & 106/131/177/192 & 192 & $\mathrm{C}_{11} \mathrm{H}_{12} \mathrm{O}_{3}$ & LS & 0.4 \\
\hline 55 & trans-4-propenylsyringol & $167 / 179 / 194$ & 194 & $\mathrm{C}_{11} \mathrm{H}_{14} \mathrm{O}_{3}$ & LS & 7.4 \\
\hline 56 & acetosyringone & $153 / 181 / 196$ & 196 & $\mathrm{C}_{10} \mathrm{H}_{12} \mathrm{O}_{4}$ & LS & 0.7 \\
\hline 57 & trans-coniferaldehyde & $107 / 135 / 147 / 178$ & 178 & $\mathrm{C}_{10} \mathrm{H}_{10} \mathrm{O}_{3}$ & LG & 0.3 \\
\hline 58 & trans-coniferyl alcohol & $124 / 137 / 151 / 180$ & 180 & $\mathrm{C}_{10} \mathrm{H}_{12} \mathrm{O}_{3}$ & $L G$ & 1.7 \\
\hline 59 & syringylacetone & $123 / 167 / 210$ & 210 & $\mathrm{C}_{11} \mathrm{H}_{14} \mathrm{O}_{4}$ & LS & 1.1 \\
\hline 60 & propiosyringone & $151 / 181 / 210$ & 210 & $\mathrm{C}_{11} \mathrm{H}_{14} \mathrm{O}_{4}$ & LS & 0.3 \\
\hline 61 & dihydrosinapyl alcohol & $167 / 168 / 212$ & 212 & $\mathrm{C}_{11} \mathrm{H}_{16} \mathrm{O}_{4}$ & LS & 0.4 \\
\hline 62 & cis-sinapyl alcohol & $154 / 167 / 210$ & 210 & $\mathrm{C}_{11} \mathrm{H}_{14} \mathrm{O}_{4}$ & LS & 0.5 \\
\hline 63 & trans-sinapaldehyde & $137 / 165 / 180 / 208$ & 208 & $\mathrm{C}_{11} \mathrm{H}_{12} \mathrm{O}_{4}$ & LS & 1.8 \\
\hline 64 & trans-sinapyl alcohol & $154 / 167 / 210$ & 210 & $\mathrm{C}_{11} \mathrm{H}_{14} \mathrm{O}_{4}$ & LS & 3.7 \\
\hline 65 & cis-sinapyl acetate & $149 / 161 / 192 / 209 / 252$ & 252 & $\mathrm{C}_{13} \mathrm{H}_{16} \mathrm{O}_{5}$ & LS & 0.4 \\
\hline \multirow[t]{5}{*}{66} & trans-sinapyl acetate & 149/161/192/209/252 & 252 & $\mathrm{C}_{13} \mathrm{H}_{16} \mathrm{O}_{5}$ & LS & 0.9 \\
\hline & $\% \mathrm{H}$ & & & & & 1.3 \\
\hline & $\% \mathrm{G}$ & & & & & 15.4 \\
\hline & $\% S$ & & & & & 83.3 \\
\hline & $S / G$ & & & & & 5.4 \\
\hline
\end{tabular}

a Main mass fragments, molecular weight (MW), formula, origin, and relative molar abundances (\%) are included. C, carbohydrates; LM, modified lignin; LH, $p$-hydroxyphenyl lignin units, H; LG, guaiacyl lignin units, G; LS, syringyl lignin units, S. Italic mass fragments indicate base peaks. 


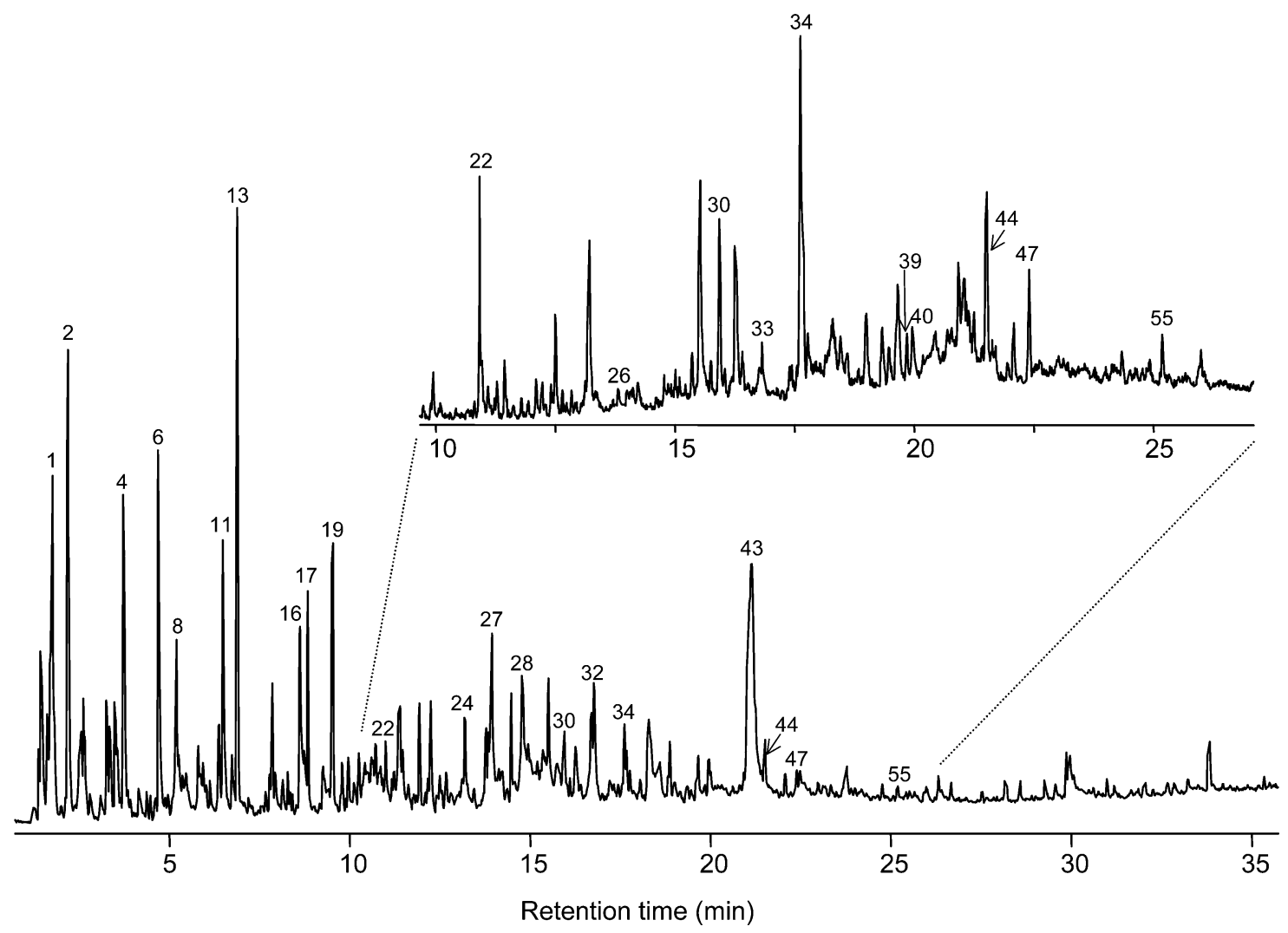

Figure 2. Py-GC/MS chromatogram of kenaf pulp. The inset illustrates a reconstructed ion chromatogram showing the main lignin markers. The reconstructed chromatogram was the sum of the molecular ions of guaiacol (22), 4-methylguaiacol (26), 4-vinylguaiacol (33), 4-ethylguaiacol (30), 4-propenylguaiacol (35), syringol (34), 4-methylsyringol (39), 4-vinylsyringol (47), 4-ethylsyringol (44), and 4-propenylsyringol (51). The identities of the compounds are listed in Table 2.

side chain and that this acetylation occurred predominantly on $\mathrm{S}$ units, in agreement with the present Py-GC/MS results. It has recently been suggested that sinapyl acetate is a lignin precursor in kenaf (29).

The chemical composition of the residual lignin in pulp after soda-AQ pulping of kenaf fibers was also studied using PyGC/MS. The main peaks in the pyrogram after Py-GC/MS of kenaf pulp corresponded to carbohydrate-derived compounds, whereas the lignin-derived peaks were very minor (Figure 2), corresponding to the low lignin content of the kenaf pulp $(<1 \%)$ (Table 1). However, by selecting characteristic ions (molecular ions) of the different lignin markers, more lignin-derived compounds could be detected in the pyrograms of the pulp sample (inset in Figure 2), which allowed the estimation of the $\mathrm{S} / \mathrm{G}$ ratio (1.1). The strong decrease in the $\mathrm{S} / \mathrm{G}$ ratio after cooking shows the preferential degradation of $\mathrm{S}$ lignin units (versus $\mathrm{G}$ units) upon alkaline pulping conditions. In this sense, the high S-lignin content observed in the kenaf bast fiber is advantageous for delignification during pulping because the $S$ lignin is relatively unbranched and has a lower condensation degree than the $\mathrm{G}$ lignin $(30,31)$.

Lipid Composition. The total lipid extract accounted for $1.0 \%$ of the kenaf bast fibers. The underivatized and silylated extracts were analyzed by GC and GC/MS. The GC/MS chromatogram of the underivatized kenaf lipids is shown in Figure 3, and the identities and abundances of the main compounds are summarized in Table 3. The most predominant lipid classes in kenaf fibers were series of $n$-fatty acids $(28 \%)$, waxes (25\%), $n$-alkanes (22\%), and $n$-fatty alcohols (14\%). Minor amounts of steroids and triterpenoids were also present in these fibers, and triglycerides were not detected.
Free fatty acids were identified in the kenaf fibers ranging from tetradecanoic $\left(\mathrm{C}_{14}\right)$ to dotriacontanoic $\left(\mathrm{C}_{32}\right)$ acids, with strong even-over-odd carbon atom predominance. Palmitic $\left(\mathrm{C}_{16}\right.$ : $0)$ and linoleic $\left(\mathrm{C}_{18: 2}\right)$ acids were the most abundant, followed by oleic $\left(\mathrm{C}_{18: 1}\right)$ and stearic $\left(\mathrm{C}_{18: 0}\right)$ acids, in agreement with previous works (17).

Waxes were found in the range from $\mathrm{C}_{42}$ to $\mathrm{C}_{52}$ with the presence of only the even carbon atom number homologues, the $\mathrm{C}_{46}$ and $\mathrm{C}_{48}$ analogues being the most abundant. Each chromatographic peak consisted of a complex mixture of different long-chain fatty acids esterified to different long-chain fatty alcohols. The identification and quantitation of the individual long-chain esters in each chromatographic peak were resolved on the basis of the mass spectra of the peaks. The mass spectra of long-chain esters are characterized by a base peak produced by a rearrangement process involving the transfer of two hydrogen atoms from the alcohol chain to the acid chain, giving a protonated acid ion (32). Therefore, the base peak gives the number of carbon atoms in the acid moiety and the molecular ion the total number of carbon atoms in the ester. It is possible then to determine the individual contribution of esters to every chromatographic peak by mass spectrometric determination of the molecular ion and the base peak. Quantitation of individual esters was accomplished by integrating areas in the chromatographic profiles of ions characteristic for the acidic moiety. The detailed structural composition of the high molecular weight waxes identified in the kenaf fiber is shown in Table 4. The esterified fatty acids ranged from $\mathrm{C}_{16}$ to $\mathrm{C}_{30}$ and the esterified fatty alcohols from $\mathrm{C}_{16}$ to $\mathrm{C}_{34}$. The acyl moiety of the waxes was exclusively constituted by saturated fatty acids with even carbon number, eicosanoic acid $\left(\mathrm{C}_{20}\right)$ being the most predomi- 

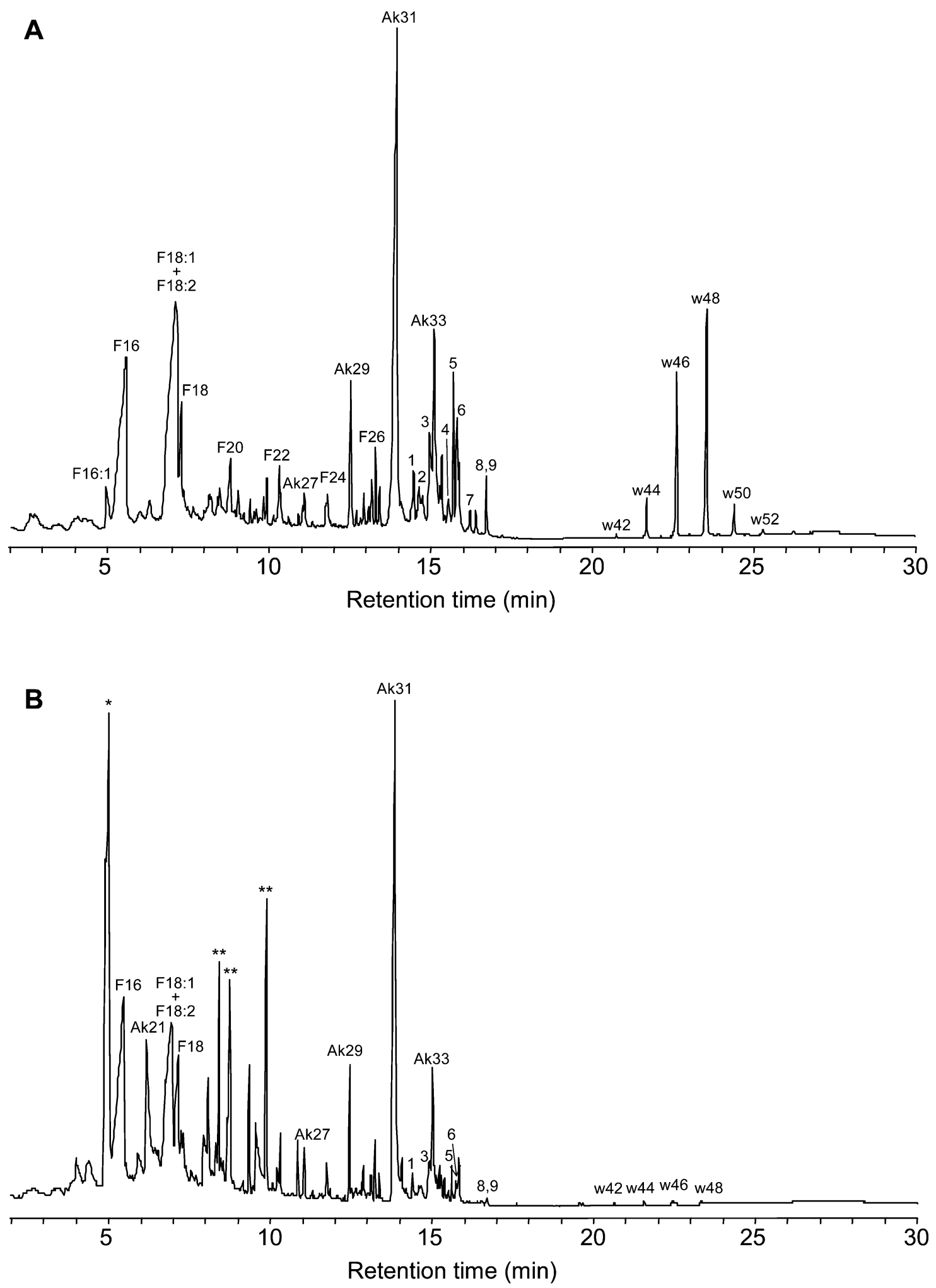

Figure 3. GC/MS chromatograms of the underivatized lipid extracts from (A) kenaf bast fibers and (B) kenaf pulp. $F(n), n$-fatty acid series; Ak(n), $n$-alkane series; $w(n)$, wax series; $n$ denotes the total carbon atom number. Other compounds reflected are (1) campesterol, (2) stigmasterol, (3) sitosterol, (4) motiol, (5) stigmast-4-en-3-one, (6) glutinol, (7) ergostane-3,6-dione, (8) stigmast-4-en-3,6-dione, and (9) stigmastane-3,6-dione. * is anthraquinone, and ${ }^{* *}$ are contaminants.

nant. Waxes with unsaturated fatty acids could not be detected, despite the high amounts of oleic and linoleic acids present in free form. Among the esterified alcohols, the most predominant was octacosanol $\left(\mathrm{C}_{28}\right)$, followed by hexacosanol $\left(\mathrm{C}_{26}\right)$ and triacontanol $\left(\mathrm{C}_{30}\right)$. The predominant wax was $\mathrm{C}_{48}$, mostly constituted by eicosanoic acid $\left(\mathrm{C}_{20}\right)$ esterified to octacosanol $\left(\mathrm{C}_{28}\right)$, followed by wax $\mathrm{C}_{46}$, mostly constituted by eicosanoic acid $\left(\mathrm{C}_{20}\right)$ esterified to hexacosanol $\left(\mathrm{C}_{26}\right)$ and octadecanoic acid $\left(\mathrm{C}_{18}\right)$ esterified to octacosanol $\left(\mathrm{C}_{28}\right)$. Before the present study, octacosanyl eicosanoate was the only wax ester reported to occur in kenaf bark fibers (17). 
Table 3. Composition of Lipids (Milligrams per $100 \mathrm{~g}$ ) from Kenaf Fibers and Their Alkaline Pulpa

\begin{tabular}{|c|c|c|c|c|c|}
\hline compound & mass fragments & MW & formula & fibers & pulp \\
\hline n-alkanes & & & & 26.88 & 20.67 \\
\hline n-heneicosane & $57 / 71 / 85 / 296$ & 296 & $\mathrm{C}_{21} \mathrm{H}_{44}$ & 0.29 & 3.36 \\
\hline$n$-tricosane & $57 / 71 / 85 / 324$ & 324 & $\mathrm{C}_{23} \mathrm{H}_{48}$ & 0.07 & 0.96 \\
\hline$n$-pentacosane & $57 / 71 / 85 / 352$ & 352 & $\mathrm{C}_{25} \mathrm{H}_{52}$ & 0.14 & 1.54 \\
\hline n-hexacosane & $57 / 71 / 85 / 366$ & 366 & $\mathrm{C}_{26} \mathrm{H}_{54}$ & 0.20 & 0.29 \\
\hline n-heptacosane & $57 / 71 / 85 / 380$ & 380 & $\mathrm{C}_{27} \mathrm{H}_{56}$ & 0.43 & 0.56 \\
\hline n-octacosane & $57 / 71 / 85 / 394$ & 394 & $\mathrm{C}_{28} \mathrm{H}_{58}$ & 0.23 & 0.31 \\
\hline$n$-triacontane & $57 / 71 / 85 / 422$ & 422 & $\mathrm{C}_{30} \mathrm{H}_{62}$ & 0.46 & 0.24 \\
\hline n-hentriacontane & $57 / 71 / 85 / 436$ & 436 & $\mathrm{C}_{31} \mathrm{H}_{64}$ & 20.48 & 11.20 \\
\hline$n$-tritriacontane & $57 / 71 / 85 / 464$ & 464 & $\mathrm{C}_{33} \mathrm{H}_{68}$ & 2.65 & 1.18 \\
\hline steroid hydrocarbons & & & & 2.32 & 0.93 \\
\hline ergostatriene & $135 / 143 / 380$ & 380 & $\mathrm{C}_{28} \mathrm{H}_{44}$ & 0.20 & 0.08 \\
\hline ergostadiene & $81 / 147 / 367 / 382$ & 382 & $\mathrm{C}_{28} \mathrm{H}_{46}$ & 0.08 & 0.03 \\
\hline stigmastadiene & $81 / 147 / 381 / 396$ & 396 & $\mathrm{C}_{29} \mathrm{H}_{48}$ & 0.46 & 0.22 \\
\hline stigmastene & $81 / 215 / 383 / 398$ & 398 & $\mathrm{C}_{29} \mathrm{H}_{50}$ & 0.20 & 0.04 \\
\hline stigmasta-3,5,22-triene & $135 / 143 / 394$ & 394 & $\mathrm{C}_{29} \mathrm{H}_{46}$ & 0.96 & 0.43 \\
\hline fatty acids & & & & 33.35 & 13.60 \\
\hline$n$-tetradecanoic acid & $60 / 73 / 129 / 228$ & 228 & $\mathrm{C}_{14} \mathrm{H}_{28} \mathrm{O}$ & 0.25 & 0.34 \\
\hline n-pentadecanoic acid & $60 / 73 / 129 / 242$ & 242 & $\mathrm{C}_{15} \mathrm{H}_{30} \mathrm{O}$ & 0.30 & 0.22 \\
\hline 9-hexadecenoic acid & $55 / 69 / 236 / 254$ & 254 & $\mathrm{C}_{16} \mathrm{H}_{30} \mathrm{O}$ & 0.09 & 0.00 \\
\hline$n$-hexadecanoic acid & $60 / 73 / 129 / 256$ & 256 & $\mathrm{C}_{16} \mathrm{H}_{32} \mathrm{O}_{2}$ & 10.87 & 5.59 \\
\hline n-heptadecanoic acid & $60 / 73 / 129 / 270$ & 270 & $\mathrm{C}_{17} \mathrm{H}_{34} \mathrm{O}_{2}$ & 0.23 & 0.18 \\
\hline 9,12 -octadecadienoic acid & $67 / 81 / 280$ & 280 & $\mathrm{C}_{18} \mathrm{H}_{32} \mathrm{O}_{2}$ & 11.79 & 1.17 \\
\hline 9-octadecenoic acid & $55 / 69 / 264$ & 282 & $\mathrm{C}_{18} \mathrm{H}_{34} \mathrm{O}_{2}$ & 5.29 & 2.53 \\
\hline n-octadecanoic acid & $60 / 73 / 129 / 284$ & 284 & $\mathrm{C}_{18} \mathrm{H}_{36} \mathrm{O}_{2}$ & 1.74 & 1.60 \\
\hline n-eicosanoic acid & $60 / 73 / 129 / 312$ & 312 & $\mathrm{C}_{20} \mathrm{H}_{40} \mathrm{O}_{2}$ & 0.86 & 1.13 \\
\hline n-docosanoic acid & $60 / 73 / 129 / 340$ & 340 & $\mathrm{C}_{22} \mathrm{H}_{44} \mathrm{O}_{2}$ & 0.91 & 0.46 \\
\hline n-tetracosanoic acid & $60 / 73 / 129 / 368$ & 368 & $\mathrm{C}_{24} \mathrm{H}_{48} \mathrm{O}_{2}$ & 0.37 & 0.17 \\
\hline n-hexacosanoic acid & $60 / 73 / 129 / 396$ & 396 & $\mathrm{C}_{26} \mathrm{H}_{52} \mathrm{O}_{2}$ & 0.17 & 0.08 \\
\hline n-octacosanoic acid & $60 / 73 / 129 / 424$ & 424 & $\mathrm{C}_{28} \mathrm{H}_{56} \mathrm{O}_{2}$ & 0.34 & 0.10 \\
\hline n-triacontanoic acid & $60 / 73 / 129 / 452$ & 452 & $\mathrm{C}_{30} \mathrm{H}_{60} \mathrm{O}_{2}$ & 0.12 & 0.03 \\
\hline n-dotriacontanoic acid & $60 / 73 / 129 / 480$ & 480 & $\mathrm{C}_{32} \mathrm{H}_{64} \mathrm{O}_{2}$ & 0.02 & 0.00 \\
\hline fatty alcohols & & & & 13.00 & 12.28 \\
\hline n-octadecanol & $75 / 103 / 355^{\star}$ & $370^{*}$ & $\mathrm{C}_{23} \mathrm{H}_{50} \mathrm{OSi}^{*}$ & 0.06 & 1.80 \\
\hline n-hexacosanol & $75 / 103 / 439^{\star}$ & $454^{*}$ & $\mathrm{C}_{29} \mathrm{H}_{62} \mathrm{OSi}^{*}$ & 1.76 & 0.90 \\
\hline$n$-octacosanol & $75 / 103 / 467^{\star}$ & $482^{*}$ & $\mathrm{C}_{31} \mathrm{H}_{66} \mathrm{OSi}^{*}$ & 8.93 & 5.36 \\
\hline$n$-triacontanol & $75 / 103 / 495^{\star}$ & $510^{*}$ & $\mathrm{C}_{33} \mathrm{H}_{70} \mathrm{OSi}^{*}$ & 2.19 & 1.58 \\
\hline n-dotriacontanol & $75 / 103 / 523^{*}$ & $538^{*}$ & $\mathrm{C}_{35} \mathrm{H}_{74} \mathrm{OSi}{ }^{*}$ & 0.01 & 0.11 \\
\hline aldehydes & & & & 0.65 & 0.04 \\
\hline$n$-heneicosanal & $82 / 96 / 292$ & 310 & $\mathrm{C}_{21} \mathrm{H}_{42} \mathrm{O}$ & 0.11 & 0.00 \\
\hline$n$-docosanal & $82 / 96 / 306$ & 324 & $\mathrm{C}_{22} \mathrm{H}_{44} \mathrm{O}$ & 0.20 & 0.00 \\
\hline$n$-tricosanal & $82 / 96 / 320$ & 338 & $\mathrm{C}_{23} \mathrm{H}_{46} \mathrm{O}$ & 0.20 & 0.00 \\
\hline$n$-tetracosanal & $82 / 96 / 334$ & 352 & $\mathrm{C}_{24} \mathrm{H}_{48} \mathrm{O}$ & 0.05 & 0.00 \\
\hline$n$-hexacosanal & $82 / 96 / 362$ & 380 & $\mathrm{C}_{26} \mathrm{H}_{52} \mathrm{O}$ & 0.02 & 0.00 \\
\hline n-octacosanal & $82 / 96 / 390$ & 408 & $\mathrm{C}_{28} \mathrm{H}_{56} \mathrm{O}$ & 0.07 & 0.04 \\
\hline sterols/triterpenols & & & & 4.71 & 0.55 \\
\hline campesterol & $55 / 145 / 213 / 382 / 400$ & 400 & $\mathrm{C}_{28} \mathrm{H}_{48} \mathrm{O}$ & 0.07 & 0.00 \\
\hline stigmasterol & $55 / 83 / 255 / 394 / 412$ & 412 & $\mathrm{C}_{29} \mathrm{H}_{48} \mathrm{O}$ & 0.19 & 0.00 \\
\hline sitosterol & $145 / 213 / 396 / 414$ & 414 & $\mathrm{C}_{29} \mathrm{H}_{50} \mathrm{O}$ & 2.33 & 0.05 \\
\hline stigmastanol & $215 / 416$ & 416 & $\mathrm{C}_{29} \mathrm{H}_{52} \mathrm{O}$ & 0.27 & 0.01 \\
\hline motiol & $69 / 83 / 241 / 259 / 411$ & 426 & $\mathrm{C}_{30} \mathrm{H}_{48} \mathrm{O}$ & 0.31 & 0.00 \\
\hline glutinol & $95 / 231 / 259 / 274$ & 426 & $\mathrm{C}_{30} \mathrm{H}_{48} \mathrm{O}$ & 1.44 & 0.19 \\
\hline$\beta$-amyrin & $203 / 218 / 426$ & 426 & $\mathrm{C}_{30} \mathrm{H}_{48} \mathrm{O}$ & 0.07 & 0.15 \\
\hline$\alpha$-amyrin & $203 / 218 / 426$ & 426 & $\mathrm{C}_{30} \mathrm{H}_{48} \mathrm{O}$ & 0.03 & 0.15 \\
\hline$\alpha$-Tocopherol & $165 / 205 / 430$ & 430 & $\mathrm{C}_{29} \mathrm{H}_{50} \mathrm{O}_{2}$ & 0.86 & 0.01 \\
\hline triterpenoid and steroid ketones & & & & 3.97 & 0.63 \\
\hline$\beta$-amyrenone & $189 / 203 / 218 / 409 / 424$ & 424 & $\mathrm{C}_{30} \mathrm{H}_{48} \mathrm{O}$ & 0.23 & 0.04 \\
\hline$\alpha$-amyrenone & $189 / 203 / 218 / 409 / 424$ & 424 & $\mathrm{C}_{30} \mathrm{H}_{48} \mathrm{O}$ & 0.07 & 0.02 \\
\hline stigmastan-3-one & $231 / 232 / 414$ & 414 & $\mathrm{C}_{29} \mathrm{H}_{50} \mathrm{O}$ & 0.07 & 0.04 \\
\hline stigmasta-7,22-dien-3-one & $55 / 269 / 298 / 367 / 410$ & 410 & $\mathrm{C}_{29} \mathrm{H}_{46} \mathrm{O}$ & 0.60 & 0.12 \\
\hline stigmasta-3,5-dien-7-one & $174 / 269 / 410$ & 410 & $\mathrm{C}_{29} \mathrm{H}_{50} \mathrm{O}$ & 0.06 & 0.09 \\
\hline stigmast-4-en-3-one & $124 / 229 / 412$ & 412 & $\mathrm{C}_{29} \mathrm{H}_{48} \mathrm{O}$ & 1.57 & 0.14 \\
\hline stigmastadienone isomer & $57 / 136 / 174 / 269 / 410$ & 410 & $\mathrm{C}_{29} \mathrm{H}_{46} \mathrm{O}$ & 0.29 & 0.18 \\
\hline ergostane-3,6-dione & $137 / 245 / 414$ & 414 & $\mathrm{C}_{28} \mathrm{H}_{46} \mathrm{O}_{2}$ & 0.23 & 0.00 \\
\hline stigmast-4-en-3,6-dione & $137 / 398 / 408 / 411 / 426$ & 426 & $\mathrm{C}_{29} \mathrm{H}_{46} \mathrm{O}_{2}$ & 0.30 & 0.02 \\
\hline stigmastane-3,6-dione & $245 / 287 / 428$ & 428 & $\mathrm{C}_{29} \mathrm{H}_{48} \mathrm{O}_{2}$ & 0.55 & 0.03 \\
\hline waxes & & & & 29.56 & 3.21 \\
\hline $\mathrm{C}_{42}$ & $57 / 71 / 257 / 620$ & 620 & $\mathrm{C}_{42} \mathrm{H}_{84} \mathrm{O}_{2}$ & 0.20 & 0.28 \\
\hline $\mathrm{C}_{44}$ & $57 / 71 / 257 / 285 / 648$ & 648 & $\mathrm{C}_{44} \mathrm{H}_{88} \mathrm{O}_{2}$ & 1.71 & 0.85 \\
\hline
\end{tabular}


Table 3 (Continued)

\begin{tabular}{|c|c|c|c|c|c|}
\hline compound & mass fragments & MW & formula & fibers & pulp \\
\hline $\begin{array}{l}\text { sterol/triterpenol esters } \\
\text { hexadecyl sitosterol } \\
\text { octadecyl sitosterol } \\
\text { hexadecyl } \beta \text {-amyrin } \\
\text { octadecyl } \beta \text {-amyrin } \\
\text { tetradecyl glutinol } \\
\text { hexadecyl glutinol } \\
\text { octadecyl glutinol } \\
\text { steryl glycosides } \\
\text { campesteryl 3- } \beta \text {-D-glucopyranoside } \\
\text { stigmasteryl 3- } \beta \text {-D-glucopyranoside } \\
\text { sitosteryl 3- } \beta \text {-D-glucopyranoside }\end{array}$ & $\begin{array}{l}147 / 381 / 396 \\
147 / 381 / 396 \\
189 / 203 / 218 \\
189 / 203 / 218 \\
259 / 274 \\
259 / 274 \\
259 / 274 \\
\\
204 / 217 / 361 / 383^{\star} \\
204 / 217 / 361 / 395^{\star} \\
204 / 217 / 361 / 397^{\star}\end{array}$ & $\begin{array}{l}652 \\
680 \\
664 \\
692 \\
636 \\
664 \\
692\end{array}$ & $\begin{array}{l}\mathrm{C}_{45} \mathrm{H}_{80} \mathrm{O}_{2} \\
\mathrm{C}_{47} \mathrm{H}_{84} \mathrm{O}_{2} \\
\mathrm{C}_{46} \mathrm{H}_{80} \mathrm{O}_{2} \\
\mathrm{C}_{48} \mathrm{H}_{84} \mathrm{O}_{2} \\
\mathrm{C}_{44} \mathrm{H}_{46} \mathrm{O}_{2} \\
\mathrm{C}_{46} \mathrm{H}_{80} \mathrm{O}_{2} \\
\mathrm{C}_{48} \mathrm{H}_{84} \mathrm{O}_{2} \\
\mathrm{C}_{46} \mathrm{H}_{90} \mathrm{O}_{6} \mathrm{Si}_{4}{ }^{*} \\
\mathrm{C}_{47} \mathrm{H}_{90} \mathrm{O}_{6} \mathrm{Si}_{4}{ }^{*} \\
\mathrm{C}_{47} \mathrm{H}_{92} \mathrm{O}_{6} \mathrm{Si}_{4}{ }^{*}\end{array}$ & $\begin{array}{l}0.59 \\
0.05 \\
0.04 \\
0.09 \\
0.05 \\
0.13 \\
0.15 \\
0.08 \\
0.38 \\
0.04 \\
0.07 \\
0.27\end{array}$ & $\begin{array}{l}0.00 \\
0.00 \\
0.00 \\
0.00 \\
0.00 \\
0.00 \\
0.00 \\
0.00 \\
0.21 \\
0.02 \\
0.04 \\
0.15\end{array}$ \\
\hline
\end{tabular}

${ }^{a}$ Main mass fragments, molecular weight (MW), and formula are included. * as TMS ether derivatives. Italic mass fragments indicate base peaks.

Table 4. Composition of the Different Waxes (Milligrams per $100 \mathrm{~g}$ ) Identified in Kenaf Fibers and Their Pulp

\begin{tabular}{|c|c|c|}
\hline $\begin{array}{l}\text { wax } \\
\text { fatty acid:fatty alcohol }\end{array}$ & fibers & pulp \\
\hline wax $C_{42}$ & 0.21 & 0.28 \\
\hline $\mathrm{C}_{16}: \mathrm{C}_{26}$ & 0.18 & 0.28 \\
\hline $\mathrm{C}_{20}: \mathrm{C}_{22}$ & 0.01 & 0.00 \\
\hline $\mathrm{C}_{22}: \mathrm{C}_{20}$ & 0.01 & 0.00 \\
\hline $\mathrm{C}_{24}: \mathrm{C}_{18}$ & 0.01 & 0.00 \\
\hline wax $\mathrm{C}_{44}$ & 1.71 & 0.86 \\
\hline $\mathrm{C}_{16}: \mathrm{C}_{28}$ & 1.31 & 0.77 \\
\hline $\mathrm{C}_{18}: \mathrm{C}_{26}$ & 0.31 & 0.09 \\
\hline $\mathrm{C}_{20}: \mathrm{C}_{24}$ & 0.05 & 0.00 \\
\hline $\mathrm{C}_{22}: \mathrm{C}_{22}$ & 0.04 & 0.00 \\
\hline wax $\mathrm{C}_{46}$ & 8.12 & 1.15 \\
\hline $\mathrm{C}_{16}: \mathrm{C}_{30}$ & 0.81 & 0.21 \\
\hline $\mathrm{C}_{18}: \mathrm{C}_{28}$ & 3.14 & 0.71 \\
\hline $\mathrm{C}_{20}: \mathrm{C}_{26}$ & 3.96 & 0.21 \\
\hline $\mathrm{C}_{22}: \mathrm{C}_{24}$ & 0.12 & 0.02 \\
\hline $\mathrm{C}_{24}: \mathrm{C}_{22}$ & 0.04 & 0.00 \\
\hline $\mathrm{C}_{26}: \mathrm{C}_{20}$ & 0.01 & 0.00 \\
\hline $\mathrm{C}_{28}: \mathrm{C}_{18}$ & 0.03 & 0.00 \\
\hline $\mathrm{C}_{30}: \mathrm{C}_{16}$ & 0.01 & 0.00 \\
\hline wax $\mathrm{C}_{48}$ & 16.97 & 0.78 \\
\hline $\mathrm{C}_{16}: \mathrm{C}_{32}$ & 0.32 & 0.00 \\
\hline $\mathrm{C}_{18}: \mathrm{C}_{30}$ & 1.18 & 0.07 \\
\hline $\mathrm{C}_{20}: \mathrm{C}_{28}$ & 14.57 & 0.57 \\
\hline $\mathrm{C}_{22}: \mathrm{C}_{26}$ & 0.75 & 0.14 \\
\hline $\mathrm{C}_{24}: \mathrm{C}_{24}$ & 0.08 & 0.00 \\
\hline $\mathrm{C}_{26}: \mathrm{C}_{22}$ & 0.01 & 0.00 \\
\hline $\mathrm{C}_{30}: \mathrm{C}_{18}$ & 0.06 & 0.00 \\
\hline wax $C_{50}$ & 1.90 & 0.14 \\
\hline $\mathrm{C}_{16}: \mathrm{C}_{34}$ & 0.01 & 0.00 \\
\hline $\mathrm{C}_{18}: \mathrm{C}_{32}$ & 0.02 & 0.00 \\
\hline $\mathrm{C}_{20}: \mathrm{C}_{30}$ & 1.73 & 0.00 \\
\hline $\mathrm{C}_{22}: \mathrm{C}_{28}$ & 0.12 & 0.14 \\
\hline $\mathrm{C}_{24}: \mathrm{C}_{26}$ & 0.02 & 0.00 \\
\hline wax $C_{52}$ & 0.40 & 0.00 \\
\hline $\mathrm{C}_{20}: \mathrm{C}_{32}$ & 0.31 & 0.00 \\
\hline $\mathrm{C}_{22}: \mathrm{C}_{30}$ & 0.03 & 0.00 \\
\hline $\mathrm{C}_{24}: \mathrm{C}_{28}$ & 0.04 & 0.00 \\
\hline $\mathrm{C}_{26}: \mathrm{C}_{26}$ & 0.02 & 0.00 \\
\hline
\end{tabular}

A series of $n$-alkanes ranging from $\mathrm{C}_{21}$ to $\mathrm{C}_{33}$ was also identified in the kenaf bast fibers with a strong odd-over-even carbon atom number predominance, hentriacontane $\left(\mathrm{C}_{31}\right)$ being the most predominant. n-Alkanes with even carbon atom numbers $\left(\mathrm{C}_{26}, \mathrm{C}_{28}\right.$, and $\left.\mathrm{C}_{30}\right)$ were also identified, albeit in lower amounts. Nonacosane $\left(\mathrm{C}_{29}\right)$ and hentriacontane $\left(\mathrm{C}_{31}\right)$ were the only alkanes previously reported in kenaf bast fiber (15), the latter being the most prominent, as found in the present work.

$n$-Fatty alcohols ranging from $\mathrm{C}_{18}$ to $\mathrm{C}_{32}$ were present in the kenaf extracts with strong even-over-odd carbon atom predominance, octacosanol $\left(\mathrm{C}_{28}\right)$ being the most abundant, as also reported by Seca et al. (17). Interestingly, the series of free fatty alcohols parallels the distribution of the esterified fatty alcohols in waxes. Minor amounts of a series of $n$-aldehydes ranging from $\mathrm{C}_{21}$ to $\mathrm{C}_{28}$ were identified in the kenaf fibers with docosanal $\left(\mathrm{C}_{22}\right)$ and tricosanal $\left(\mathrm{C}_{23}\right)$ predominating. This series of compounds has not been reported before in kenaf fibers.

Sterols and triterpenols were also present among the lipids of kenaf fibers. Sitosterol was the most abundant among the free sterols, with the presence of minor amounts of campesterol, stigmasterol, and stigmastanol. Lower amounts of sitosterol could also be found in ester form. Steryl glycosides, such as campesteryl, stigmasteryl, and sitosteryl $\beta$-D-glucopyranosides, were identified in minor amounts, the latter being the most predominant. The identification of steryl glycosides was accomplished (after BSTFA derivatization of the lipid extract) by comparison with the mass spectra and relative retention times of authentic standards (33). To our knowledge, the existence of the latter compounds in kenaf fibers is reported here for the first time. Among triterpenols, $\beta$ - and $\alpha$-amyrins occurred in free form, and a low amount of $\beta$-amyrin was also present in esterified form. Two other triterpenols, both characterized by a base peak at $\mathrm{m} / \mathrm{z}, 259$ and molecular ions at $\mathrm{m} / \mathrm{z}$ 426, were identified as motiol and glutinol. These compounds were also reported in kenaf bast fibers, and the structure of motiol was subsequently confirmed by NMR by Seca et al. (17). A series of high molecular weight compounds with mass spectra characterized by fragments at $\mathrm{m} / \mathrm{z} 259$ and 274 , similar to that of free glutinol, were present in the extracts and were tentatively identified as glutinol esters. Lupeol, which was reported to occur in relatively high amount in kenaf (17), could not be detected here. Finally, several steroid hydrocarbons (such as stigmasta3,5-diene and stigmasta-3,5,22-triene) and steroid and triterpenoid ketones (such as stigmast-4-en-3-one, stigmastan-3-one, stigmasta-7,22-dien-3-one, and $\beta$ - and $\alpha$-amyrenones) were also identified.

To investigate the fate of the different kenaf lipids during cooking, the lipid composition of an alkaline pulp with kappa 6 was studied. The GC/MS chromatogram of the underivatized pulp lipids, which accounted for $0.3 \%$ (Table 1), is shown in Figure 3, and the composition is listed in Table 3. It can be observed that the different lipid classes had different behaviors during cooking. The main difference in the lipid composition of kenaf pulp with respect to kenaf fibers concerned the amount of waxes, which showed a strong decrease, accounting for only $6 \%$ of the total lipids identified in pulp. The low wax content in the pulp of kappa 6 is due to the extensive hydrolysis of wax esters during alkaline cooking. The fatty acid content also decreased after cooking. At sufficiently high $\mathrm{pH}$ (as in alkaline pulping), the acids dissociate and form fatty acid soaps and can 
thus dissolve in water to quite a high extent, forming fatty acid soaps. On the other hand, alkanes, fatty alcohols, sterols and triterpenols, steroid hydrocarbons and ketones, and steryl glycosides survived cooking. These compounds have a very low solubility in water and are difficult to remove and, therefore, can cause pitch problems. Steryl glycosides were present in minor amounts in the pulp. These compounds contain both hydrophilic and hydrophobic sites, have high melting points, and have very low solubility in water, alkali, and usual organic solvents. Due to these properties, they constitute protecting layers that prevent the cooking and bleaching chemicals from reaching the lipids (34). Problems caused by these compounds are increased in closed water systems.

In conclusion, the present work has shown different behaviors of lignin and lipids from the kenaf fibers during soda-AQ cooking. Knowledge of the chemical composition of the main components of nonwood plants and their behavior in pulping will be useful for a better utilization of nonwood plants. Nevertheless, further studies and efforts will be necessary to improve the industrial use of nonwood plants. The fiber demands of the industry should also be translated to agricultural production of high-quality fiber raw material.

\section{ACKNOWLEDGMENT}

We thank CELESA (Tortosa, Spain) for providing the kenaf and pulp samples, S. Camarero (CIB, CSIC, Madrid) for Klason lignin and hemicellulose analyses, and A. T. Martínez (CIB, CSIC, Madrid) for critical reading of the manuscript.

\section{LITERATURE CITED}

(1) Moore, G. Nonwood Fibre Applications in Papermaking; Pira International: Leatherhead, Surrey, U.K., 1996.

(2) Kaldor, A. F.; Karlgren, C.; Verwest, H. Kenaf-A fast growing fiber source for papermaking. Tappi J. 1990, 78, 205-209.

(3) Sabharwal, H. S.; Akhtar, M.; Blanchette; R. A.; Young, R. A. Biological pulping of kenaf. Tappi J. 1944, 77, 105-112.

(4) Ahmed, A.; Scott, G. M.; Akhtar, M.; Myers, G. G. Biokraft pulping of kenaf and its bleachability. TAPPI North American Nonwood Fiber Symposium, Atlanta, GA, 1998; pp 231-238.

(5) Han, J. S.; Rymsza, T. A. Determining the minimum conditions for soda-AQ pulping of kenaf bast, core, and whole stalk fibers. Presented at the Second Annual American Kenaf Society Conference, San Antonio, TX, 1999.

(6) del Río, J. C.; Gutiérrez, A.; Hernando, M.; Landín, P.; Romero, J.; Martínez, A. T. Correlation between lignin syringyl/guaiacyl ratio in eucalypt wood and paper pulp yield. Presented at the 16th International Symposium on Analytical and Applied Pyrolysis, Alicante, Spain, 2004 p 165.

(7) Hillis, W. E.; Sumimoto, M. Effect of extractives on pulping. In Natural Products of Woody Plants II; Rowe, J. W., Ed; Springer-Verlag, Berlin, Germany, 1989; pp 880-920.

(8) Back, E. L.; Allen, L. H. Pitch Control, Wood Resin and Deresination; Tappi Press: Atlanta, GA, 2000.

(9) Gutiérrez, A.; del Río, J. C.; Martínez, M. J.; Martínez, A. T. The biotechnological control of pitch in paper pulp manufacturing. Trends Biotechnol. 2001, 19, 340-348.

(10) Ali, M.; Sreekrishnan, T. R. Aquatic toxicity from pulp and paper mill effluents: A review. Adv. Environ. Res. 2001, 5, 175-196.

(11) Ralph, J. An unusual lignin from kenaf. J. Nat. Prod. 1996, 59, 341-342.

(12) Neto, C. P.; Seca, A. M. L.; Fradinho, D.; Coimbra, M. A.; Domingues, F. M. J.; Evtuguin, D.; Silvestre, A. J. D.; Cavaleiro, J. A. S. Chemical composition and structural features of the macromolecular components of Hibiscus cannabinus grown in Portugal. Ind. Crops Prod. 1996, 5, 189-196.

(13) Seca, A. M. L.; Cavaleiro, J. A. S.; Domingues, F. M. J.; Silvestre, A. J. D.; Evtuguin, D.; Neto; C. P. Structural characterization of the bark and core lignins from kenaf (Hibiscus cannabinus). J. Agric. Food Chem. 1998, 46, 3100-3108.

(14) Morrison, W. H., III.; Akin, D. E.; Archibald, D. D.; Dodd, R. B.; Raymer, P. L. Chemical and instrumental characterization of maturing kenaf core and bast. Ind. Crops Prod. 1999, 10, 21-34.

(15) Nishimura, N.; Izumi, A.; Kuroda, K. Structural characterization of kenaf lignin: Differences among kenaf varieties. Ind. Crops Prod. 2002, 15, 115-122.

(16) Kuroda, K.; Izumi, A.; Mazumder, B. B.; Ohtani, Y.; Sameshima, K. Characterization of kenaf (Hibiscus cannabinus) lignin by pyrolysis-gas chromatography-mass spectrometry in the presence of tetramethylammonium hydroxide. J. Anal. Appl. Pyrolysis 2002, 64, 453-463.

(17) Seca, A. M. L.; Silva, A. M. S.; Silvestre, A. J. D.; Cavaleiro, J. A. S.; Domingues, F. M. J.; Neto, C. P. Chemical composition of the light petroleum extract of Hibiscus cannabinus bark and core. Phytochem. Anal. 2000, 11, 345-350.

(18) Faix, O.; Meier, D.; Fortmann, I. Thermal degradation products of wood. A collection of electron-impact (EI) mass spectra of monomeric lignin derived products. Holz Roh- Werkst. 1990, $48,351-354$.

(19) Ralph, J.; Hatfield, R. D. Pyrolysis-GC/MS characterization of forage materials. J. Agric. Food Chem. 1991, 39, 1426-1437.

(20) Gutiérrez, A.; del Río, J. C.; González-Vila, F. J.; Martín, F. Analysis of lipophilic extractives from wood and pitch deposits by solid-phase extraction and gas chromatography. J. Chromatogr. A 1998, 823, 449-455.

(21) Holton, H. H. Soda additive softwood pulping: A major new process. Pulp Paper Can. 1977, 78, T218.

(22) Technical Association of the Pulp and Paper Industry. Test Methods, 1992-1993; TAPPI: Atlanta, GA, 1993.

(23) Bocchini, P.; Galletti, G. C.; Camarero, S.; Martínez, A. T. Absolute quantitation of lignin pyrolysis products using an internal standard. J. Chromatogr. A 1997, 773, 227-232.

(24) van Dam, J. E. G.; van Vilsteren, G. E. T.; Zomers, F. H. A.; Shannon, W. B.; Hamilton, I. T. Increased Application of Domestically Produced Plant Fibres in Textiles, Pulp and Paper Production and Composite Materials; Directorate-General XII, Science, Research and Development, European Commission: Brussels, Belgium, 1994.

(25) Gutiérrez, A.; del Río, J. C. Lipids from flax fibers and their fate in alkaline pulping. J. Agric. Food Chem. 2003, 51, 49654971.

(26) Gutiérrez, A.; del Río, J. C. Lipids from flax fibers and their fate in alkaline pulping. J. Agric. Food Chem. 2003, 51, 69116914 (Addition/Correction).

(27) del Río, J. C.; Gutiérrez, A.; Martínez, A. T. Identifying acetylated lignin units in non-wood fibers using pyrolysis-gas chromatography/mass spectrometry. Rapid Commun. Mass Spectrom. 2004, 18, 1181-1185.

(28) Ralph, J.; Lu, F. The DFRC method for lignin analysis. A simple modification for identifying natural acetates on lignins. J. Agric. Food Chem. 1998, 46, 4616-4619.

(29) Lu, F.; Ralph, J. Preliminary evidence for sinapyl acetate as a lignin monomer in kenaf. Chem. Commun. 2002, 90-91.

(30) Nimz, H. Beech lignin-Proposal of a constitutional scheme. Angew. Chem. Int. Ed. 1974, 13, 313-321.

(31) Adler, E. Lignin chemistry-Past, present and future. Wood Sci. Technol. 1977, 11, 169-218.

(32) Sharkey, A. G., Jr.; Shultz, J. L.; Friedel, R. A. Mass spectra of esters. Formation of rearrangement ions. Anal. Chem. 1959, 31, 87-94. 
(33) Gutiérrez, A.; del Río, J. C. Gas chromatography/mass spectrometry demonstration of steryl glycosides in eucalypt wood, Kraft pulp and process liquids. Rapid Commun. Mass Spectrom. 2001, 15, 2515-2520.

(34) Nilvebrant, N.-O.; Byström, S. Demonstration of glucosidic linked sterols in birch. Proceedings of the 8th International Symposium on Wood and Pulping Chemistry; Gummens Kirjapaino Oy, Jyväskylä: Helsinki, Finland, 1995; pp 135-140.
Received for review March 22, 2004. Revised manuscript received May 17, 2004. Accepted May 24, 2004. This study has been supported by the Spanish Ministerio de Ciencia y Tecnología (MCyT) and FEDER funds (Project AGL2002-00393). A.G. acknowledges a "Ramón y Cajal" contract of the Spanish MCyT.

JF049540W 